\title{
A Novel Barrier Device and Method for Protection against Airborne Pathogens During Endotracheal Intubation
}

\section{Running Head: A Novel Barrier Device for Endotracheal Intubation.}

Julio M. Alonso M.D. ${ }^{1,2}$, Jeffrey Lipman M.D., Ph.D. ${ }^{2,3,4}$, Kiran Shekar M.D., Ph.D. ${ }^{1,5}$

${ }^{1}$ Adult Intensive Care Services and Critical Care Research Group, The Prince Charles Hospital, Brisbane, Queensland, Australia

${ }^{2}$ The University of Queensland, Brisbane. Queensland, Australia

${ }^{3}$ Jamieson Trauma Institute and Intensive Care Services, Royal Brisbane and Women's Hospital, Brisbane

${ }^{4}$ Nimes University Hospital, University of Montpellier, Nimes, France

${ }^{5}$ Queensland University of Technology, Brisbane; University of Queensland, Brisbane; and Bond University, Gold Coast. Queensland, Australia

\section{Address correspondence to:}

Dr Julio M Alonso.

Adult Intensive Care Services. The Prince Charles Hospital.

Rode Road. Chermside West. QLD 4032. Australia

Phone: +61 434940786

E-mail: j.alonsobabarro@uq.edu.au 


\section{ABSTRACT}

\section{Background}

3 The risk of SARS-CoV-2 transmission to healthcare workers increases during aerosol-

4 generating procedures such as endotracheal intubation.

\section{Objectives}

6 We tested the effectiveness of a novel barrier mouthpiece in reducing clinician exposure

7 to aerosols and droplets during endotracheal intubation.

\section{Design}

9 A prospective case control study was carried out, with a single operator performing

10 eight simulated intubations with and without the device on two different high-fidelity

11 manikin models which produced aerosols and droplets.

\section{Setting}

13 The study was performed during June 2020, at the Clinical Skills Development Service, 14 Brisbane, Australia.

\section{Interventions}

16 Simulated scenarios included 1) intubation during cardiopulmonary resuscitation 2)

17 intubation while pre-oxygenating via high flow nasal cannula. Photographic images 18 were obtained during each intubation and digitally analyzed using ImageJ v2.1.0/1.53c.

\section{Patients}

20 Not applicable.

\section{Main outcome measures}

22 Aerosol and droplets were quantified using pixel counts. Overall results were expressed 23 as means ( $\pm \mathrm{SD})$, with comparisons between groups made using a two-tailed Student's

24 T-test under the assumption of unequal variances. A $\mathrm{P}$ value of $\leq 0.05$ was considered 25 as statistically significant.

\section{Results}

27 First pass intubation was achieved in all scenarios, with and without the barrier device.

28 Pixel counts demonstrated significant overall reduction in aerosol and droplet exposure 29 when the barrier device was used during intubation [Mean (SD) count:509 (860) vs 
medRxiv preprint doi: https://doi.org/10.1101/2022.01.24.22269341; this version posted January 25, 2022. The copyright holder for this preprint

(which was not certified by peer review) is the author/funder, who has granted medRxiv a license to display the preprint in perpetuity.

All rights reserved. No reuse allowed without permission.

3010169 (11600); $\mathrm{P}=0.014]$. The highest exposure risk to airborne particles was observed

31 during simulated induction, prior to laryngoscopy and intubation.

\section{Conclusions}

33 The novel barrier device was effective in reducing environmental exposure to aerosols

34 and droplets during intubation without negatively affecting first pass intubation. The

35 highest risk of exposure to airborne particles was during induction, before intubation

36 takes place. Clinical trials are indicated to further test the feasibility and efficacy of this

37 device.

38 Trial registration

39 Not applicable.

40 Keywords: Endotracheal intubation, SARS-CoV-2, COVID-19, Prevention, Safety 
medRxiv preprint doi: https://doi.org/10.1101/2022.01.24.22269341; this version posted January 25, 2022. The copyright holder for this preprint

(which was not certified by peer review) is the author/funder, who has granted medRxiv a license to display the preprint in perpetuity.

All rights reserved. No reuse allowed without permission.

\section{KEY POINTS}

43 - This prospective, preclinical study represents a pilot trial of a novel barrier mouthpiece for reducing clinician exposure to aerosols and droplets during endotracheal intubation.

- In eight simulated intubations with and without the barrier mouthpiece, the device proved effective in reducing environmental exposure to aerosols and droplets (measured in pixels) during intubation, without negatively affecting first pass intubation.

- The novel barrier mouthpiece represents a possible solution for reducing the risk of respiratory pathogen transmission during endotracheal intubation without hampering the procedure itself, although larger preclinical and clinical trials are necessary. 


\section{Background}

56 From December 2019 - when the first cases of novel SARS-CoV-2 infection were 57 described $^{1}$ - to May 2020 alone, over 152,888 healthcare workers had already been 58 infected by the virus ${ }^{2}$, accounting for up to $17.2 \%$ of hospital admissions (including 59 healthcare workers' households) for COVID- $19^{3}$. Subsequent studies have confirmed 60 that COVID-19 is an airborne disease ${ }^{4,5}$, pointing to an increased risk of transmission 61 during aerosol generating procedures such as cardiopulmonary resuscitation (CPR) or 62 endotracheal intubation (ETI), a procedure performed in up to $20 \%$ of severely ill 63 patients with COVID-19 ${ }^{6}$. Worldwide shortages of personal protective equipment 64 (PPE), especially in under-resourced environments and developing countries, have led 65 to increased concerns about inequalities regarding access to necessary protection for 66 healthcare workers during this and other procedures ${ }^{7}$. On the other hand, PPE itself 67 may not be the panacea for eliminating the risk of SARS-CoV-2 transmission during aerosol-generating procedures. In their observational cohort, Boghdadly et. al describe around 10\% incidence of COVID-19 symptoms in healthcare workers involved in the ETI of patients with the disease, despite the majority wearing adequate PPE as defined by the World Health Organization ${ }^{8}$.

To provide an extra level of protection for frontline workers during intubation of COVID-19 patients, recent publications have documented the rise of initiatives such as 'intubation teams' comprising of experienced anesthesiologists ${ }^{9,10}$, ad hoc intubation protocols ${ }^{11}$, dedicated negative pressure rooms ${ }^{12}$, and protective barrier enclosures, of which the best-known example is the 'aerosol box', designed by Dr. Hsien Yung Lai, a

77 Taiwanese anesthesiologist ${ }^{13}$. Further versions of the aerosol box, including the 78 addition of a negative-pressure chamber, have also been developed ${ }^{14}$. However, despite initial traction and widespread use in clinical practice, subsequent studies in simulation models and clinical practice ${ }^{15}$ have provided evidence that these devices could pose a risk for patient safety, due to increased intubation times ${ }^{16}$. In addition, these devices may hamper access to the airway, and may paradoxically increase healthcare worker infection rates because of increased exposure to aerosols during removal of the barrier enclosure $^{17}$. These findings led to the FDA withdrawing its Emergency Use Approval for protective barrier enclosures in August 2020. 
86 To the best of our knowledge, no current alternative to protective barrier enclosures

87 exists that offers an extra layer of protection for physicians and their teams during 88 intubation of patients with COVID-19 or other respiratory infections, while ensuring

89 correct access to the airway and guaranteeing the feasibility of the procedure. Therefore, 90 we designed a barrier mouthpiece - the Airway Shield ${ }^{\mathrm{TM}}$ - which restricts the spread of 91 aerosols and droplets during the endotracheal intubation procedure by covering the 92 patient's mouth, while facilitating intubation itself via a cannula that is inserted between 93 the patient's tongue and the palate, allowing the introduction of the laryngoscope's 94 blade and the endotracheal tube, and guiding the endotracheal tube towards the larynx.

95 The objective of our study is to evaluate the effectiveness of this novel device regarding 96 the reduction of aerosols and droplets liberated during ETI, compared to conventional 97 intubation without the device. Secondary objectives include assessing the feasibility of 98 endotracheal intubation with the device, measured as first pass intubation, and 99 quantifying the risk of aerosol and droplet spread in different moments of the procedure. 
101

102

103

104

106

107

108

\section{Methods}

The study was carried out at the Clinical Skills Development Service (CSDS) in Brisbane, Australia, during June 2020. This institution provides simulation-based training for healthcare professionals from the Queensland Health workforce and offers a large range of devices and venues for preclinical research.

The study was designed to evaluate Airway Shield's efficacy in reducing droplet (airborne particles $>5 \mu \mathrm{m}$ in diameter) and aerosol (airborne particles $<5 \mu \mathrm{m}$ in diameter $)^{18}$ exposure when performing ETI during CPR and during controlled ETI while maintaining oxygenation with High Flow Nasal Canula (HFNC), with and without Airway Shield. High-fidelity simulated ETIs were performed on manikins capable of producing droplets and aerosols. Imaging software (ImageJ) was used to measure and compare the spread of droplets and aerosols in the different scenarios.

\section{Ethics}

Our study was carried out in accordance with the ethical principles set out in the Declaration of Helsinki. Ethical approval for this study was not required as no animals or human patients were involved.

\section{Device characteristics}

The device tested in this study was a 3-D printed prototype, built in medical grade TPU material with a Shore A hardness durometer scale of 80 , specifically chosen to give a consistency that maintains and recovers its form, while being soft enough to avoid damage of the mucosa of a patient when introduced through the mouth and placed between the palate and the tongue (Figures 1, 2 and 3). This novel barrier device has three main components: A shield, to cover the patient's mouth; a working channel, with two openings, a proximal one, at the level of the shield, and a distal one at the other end; and a seal, to cover the proximal opening and restrict aerosol spread while permitting the insertion of the blade of a laryngoscope and the endotracheal tube through it. Additionally, two small, sealed openings at both sides of the main proximal opening at the level of the shield, provide access for catheters for the suction of fluids or aerosols during ETI (Figures 1 and 2).

\section{Technique of intubation with the novel device}


131 Endotracheal intubation with the Airway Shield is performed in 3 steps. First, during

132

133

134

135 induction, the device is placed: the working channel is introduced into the mouth of the patient following the palate, until the shield covers the mouth. Second, ETI is performed: as in a standard ETI, the video-laryngoscope blade is introduced first to obtain a view of the larynx, followed by the ETT (endotracheal tube), in this case following the blade through the working channel, towards the larynx. Finally, the Airway Shield is removed: once the ETT is in place and the ventilator is connected, the device is peeled away from the midline and removed. (Figure 3 and Additional File 2: multimedia content).

\section{Manikin preparation}

For this study, we designed two different manikin models to produce aerosols and droplets. To simulate and evaluate the spread of aerosols during the intubation procedure, a resuscitation manikin (Megacode Kelly, Laerdal) was modified by connecting a nebulizer (Aerogen Solo, Aerogen) for inhalation to the reservoir bag of a self-inflating bag connected to the lungs, and powered by a ventilator (Servo U, Maquet), thus permitting the nebulization of an ultraviolet light-sensitive fluid into the simulated airway. Continuous airflow (6L/minute) was applied to the nebulizer to ensure sufficient aerosol visualization. To evaluate the spread of droplets, an atomizer connected by a long tubing to a syringe containing colored fluid (green dye mixed with water) was placed at the level of the manikin's oropharynx, pointing towards the mouth (Additional File 1: Manikin Preparation).

\section{Simulated endotracheal intubation}

We tested the device for the environmental exposure of both aerosols and droplets in two different scenarios - intubation during cardiopulmonary resuscitation (CPR) and intubation during oxygenation with high flow nasal cannula (HFNC) - and compared the results with those obtained in the same scenarios during conventional intubation. A total of eight simulated intubations were performed by a single operator, with first pass intubation recorded as a dichotomous variable (yes/no). The same sequence of simulations was followed for the scenarios evaluating the spread of droplets. (Further documentation on the complete sequence of events is available in Appendix C and D)

During the simulations, photographs were taken at a rate of 6 frames per second to capture data on the spread of aerosols and droplets at three moments of each simulated 
163 clinical scenario: just before introduction of the laryngoscope into the manikin's mouth

164 (corresponding to anesthetic induction); during initial laryngoscopy; and during the

165 introduction of the endotracheal tube. The spread of aerosols and droplets was

166 documented by photographs taken from a fixed angle against a dark background. In

167 order to quantify and compare results, the photograph showing the highest spread of

168 aerosols and droplets was chosen for each scenario. All photographs measured $1920 \mathrm{x}$

1691280 pixels.

\section{Data analysis}

171 Images from each scenario were selected according to the maximum count of droplets

172 or aerosols in each setting and were converted from color to black and white in order to

173 permit digital analysis. A manual polygonal selection of the areas in which aerosols and

174 droplets were visualized was carried out. Captured data were analyzed with detection

175 and automatic count of aerosols and droplets using ImageJ v2.1.0/1.53c, an open-source

176 package for the processing and analysis of scientific images.

177 Aerosol and droplets were quantified using pixel counts. Overall results were expressed

178 as means ( $\pm \mathrm{SD}$ ), with the comparison between groups made using a two-tailed

179 Student's T-test under the assumption of unequal variances. A P value of 0.05 or less

180 was considered to indicate statistical significance. Statistical analysis of the results was

181 carried out using R version 4.1.0 ( 2021 The R Foundation for Statistical Computing). 


\section{Results}

18624 images were selected for digital analysis using automatic pixel counts (Figures 4 and 1875 and Additional File 3), after previous manual selection of the area in which aerosols 188 or droplets had been detected. Pixel counts demonstrated significant overall reduction of 189 aerosols and droplets during ETI in high-fidelity clinical simulations with Airway 190 Shield compared to intubation without the device (509 (859.96) vs 10168.91 191 (11600.63); $\mathrm{P}=0.014$ ), as shown in Table 1. When analyzed by subgroups (Table 2), 192 Airway Shield reduced the spread of aerosols by 12-fold on average $(\mathrm{P}=0.045)$. The 193 spread of droplets was reduced by an average of 43-fold, although this result was not 194 statistically significant.

195 First pass success was achieved in all clinical scenarios, both with and without Airway 196 Shield. The operator did not describe difficulty while carrying out the procedure in any 197 of the simulated intubation scenarios.

198 Regarding the risk of aerosol and droplet spread during the different moments of the 199 endotracheal intubation procedure, highest counts of airborne particles were observed 200 during simulated induction, before carrying out initial laryngoscopy and intubation 201 (Figure 6). This difference was maintained in both CPR and HFNC scenarios, 202 independently of whether Airway Shield was used. 


\section{Discussion}

205

206

The primary objective of our study was to test Airway Shield's potential for reducing the spread of aerosols and droplets during ETI, as compared to intubation without the device. We simulated clinical scenarios in specifically designed manikin models and used automatic pixel counts as a surrogate marker of the reduction in spread of droplets and aerosols generated by patients in real-life settings. Our results showed that this novel barrier mouthpiece demonstrated significant overall reduction of airborne particles, while permitting a consistent first pass success rate in all simulated intubations. These findings confirm Airway Shield's effectiveness as a barrier device against aerosols and droplets, while at the same time permitting successful ETI.

Our results offer a novel perspective on barrier devices designed to reduce exposure to airborne particles during intubation. This study is the first to present a specifically designed mouthpiece which demonstrates effective protection from aerosols and droplets while permitting successful ETI. The novelty of this device stems from the fact that it successfully covers the patient's mouth without impeding first pass intubation.

Regarding the risk of aerosol and droplet spread during the different moments of the endotracheal intubation procedure, our study demonstrated a consistently higher count of airborne particles during induction in all but one scenario. To our knowledge, this study is the first to address the risk of exposure to aerosols and droplets at specific moments of the procedure. Although the number of experiments is too small to permit statistical comparison, we raise the hypothesis that induction may be the moment of highest risk for healthcare professionals carrying out the intubation procedure.

Our study has four main limitations. First, it is a preclinical study in manikin models, using pixel counts as surrogate markers for the aerosols and droplets generated by patients during ETI. Second, the possibility of small variations in the flow of aerosols and droplets produced by the manikins cannot be completely eliminated. Third, the manual polygon selection process may affect reproducibility of the results. Finally, the number of simulated scenarios is relatively small; however, the variations in aerosol and droplet spread are large enough to permit statistically significant conclusions.

\section{Conclusions}


medRxiv preprint doi: https://doi.org/10.1101/2022.01.24.22269341; this version posted January 25, 2022. The copyright holder for this preprint

(which was not certified by peer review) is the author/funder, who has granted medRxiv a license to display the preprint in perpetuity.

All rights reserved. No reuse allowed without permission.

235 Our study suggests that Airway Shield, a novel barrier mouthpiece, is effective in

236 reducing the spread of aerosols and droplets during ETI, while permitting successful

237 first pass intubation. The results offer a novel perspective on barrier devices and open

238 the door to the possibility of using a mouthpiece to protect healthcare workers during

239 ETI, an aerosol generating procedure. Our findings also generate the hypothesis that the

240 moment of highest risk of exposure to airborne particles is, in fact, during induction,

241 before the actual intubation takes place.

242 Further research is necessary to confirm these findings, including larger simulation

243 studies and clinical trials to evaluate safety and efficacy of Airway Shield. 
medRxiv preprint doi: https://doi.org/10.1101/2022.01.24.22269341; this version posted January 25, 2022. The copyright holder for this preprint

(which was not certified by peer review) is the author/funder, who has granted medRxiv a license to display the preprint in perpetuity.

All rights reserved. No reuse allowed without permission.

\section{Acknowledgements relating to this article:}

\section{Assistance with the article:}

248 The authors would like to thank the 'Clinical Skills Development Service' in Brisbane

249 and Clinton Henderson for their contribution setting up the manikins used for the study,

250 Cambell Smyth for his contribution in the CAD design of the device and the drawings

251 presented in this article, Joanne Zuo for her contribution with the digital data analysis,

252 Jose Medrano for his suggestions for the design of the study, and Sergio Lordao and

253 Michael Minoza for their contribution taking the photos and video.

254

255 Financial support and sponsorship: None

256 Conflicts of interest: J.M.A. has created the concept and design of the Airway

257 Shield $^{\mathrm{TM}}$ and has filed an international patent for commercial use. J.L. and K.S. have no

258 conflicts of interest to declare.

260 Presentations: None 
medRxiv preprint doi: https://doi.org/10.1101/2022.01.24.22269341; this version posted January 25, 2022. The copyright holder for this preprint (which was not certified by peer review) is the author/funder, who has granted medRxiv a license to display the preprint in perpetuity.

All rights reserved. No reuse allowed without permission.

\section{References}

1. Ge H, Wang X, Yuan X, et al. The epidemiology and clinical information about COVID-19. Eur J Clin Microbiol Infect Dis. 2020;39(6):1011-9.

2. Bandyopadhyay S, Baticulon RE, Kadhum M, et al. Infection and mortality of healthcare workers worldwide from COVID-19: a systematic review. BMJ Glob Health. 2020;5(12):e003097.

3. Shah AS, Wood R, Gribben C, et al. Risk of hospital admission with coronavirus disease 2019 in healthcare workers and their households: nationwide linkage cohort study. BMJ. 2020;371:m3582

4. Wilson NM, Marks GB, Eckhardt A, et al. The effect of respiratory activity, non $\square$ invasive respiratory support and facemasks on aerosol generation and its relevance to COVID $\square$ 19. Anaesthesia [online ahead of print] 30 March 2021; https://associationofanaesthetistspublications.onlinelibrary.wiley.com/doi/10.1111/anae.15475

5. Weissman DN, De Perio MA, Radonovich LJ. COVID-19 and risks posed to personnel during endotracheal intubation. JAMA. 2020;323(20):2027-8.

6. Halpern NA, Tan KS. United States resource availability for COVID-19. Critical Care Statistics. 2020. https://sccm.org/Blog/March-2020/United-States-ResourceAvailability-for-COVID-19?_zs=jxpjd1\&_zl=w9pb6. Accessed 27 JUL 2021.

7. Minayo MC de S, Freire NP. The pandemic exacerbates health inequalities. Cien Saude Colet. 2020;25:3555-6.

8. El $\square$ Boghdadly K, Wong DJN, Owen R, et al. Risks to healthcare workers following tracheal intubation of patients with COVID $\square$ 19: a prospective international multicentre cohort study. Anaesthesia. 2020;75(11):1437-47.

9. Cook TM, El $\square$ Boghdadly K, McGuire B, McNarry AF, Patel A, Higgs A. Consensus guidelines for managing the airway in patients with COVID $\square$ 19: Guidelines from the Difficult Airway Society, the Association of Anaesthetists the Intensive Care 
medRxiv preprint doi: https://doi.org/10.1101/2022.01.24.22269341; this version posted January 25, 2022. The copyright holder for this preprint (which was not certified by peer review) is the author/funder, who has granted medRxiv a license to display the preprint in perpetuity.

All rights reserved. No reuse allowed without permission.

Society, the Faculty of Intensive Care Medicine and the Royal College of Anaesthetists. Anaesthesia. 2020;75(6):785-99.

10. Gandhi A, Sokhi J, Lockie C, Ward PA. Emergency tracheal intubation in patients with COVID-19: experience from a UK Centre. Anesthesiology research and practice. [Serial online] 2020 Dec [Cited 2021 Jul 27]. Available from: https://www.hindawi.com/journals/arp/2020/8816729/

11. Miller L, Luković E, Wagener G. Guiding airway management and personal protective equipment for COVID-19 intubation teams. Br J Anaesth. 2020;125(3):e288-90.

12. Matava CT, Kovatsis PG, Summers JL, et al. Pediatric airway management in Coronavirus disease 2019 patients: consensus guidelines from the society for pediatric anesthesia's pediatric difficult intubation collaborative and the Canadian pediatric anesthesia society. Anesth Analg [Online ahead of print] 13 Apr 2020; https://www.ncbi.nlm.nih.gov/pmc/articles/PMC7173403/

13. Malik JS, Jenner C, Ward PA. Maximising application of the aerosol box in protecting healthcare workers during the COVID $\square 19$ pandemic. Anaesthesia. 2020;75(7):974.

14. Gupta V, Sahani A, Mohan B, Wander GS. Negative pressure aerosol containment box: An innovation to reduce COVID-19 infection risk in healthcare workers. J Anaesthesiol Clin Pharmacol. 2020;36(Suppl 1):S144.

15. Tighe NT, McClain CD, Vlassakova BG, et al. Aerosol barriers in pediatric anesthesiology: Clinical data supports FDA caution. Pediatr Anaesth. 2021;31(4):461-4.

16. Lim ZJ, Reddy MP, Karalapillai D, Shekar K, Subramaniam A. The impact of an aerosol box on time to tracheal intubation: systematic review and meta-analysis. $\mathrm{Br}$ J Anaesth. 2021; 126(3):e122-e125

17. Begley JL, Lavery KE, Nickson CP, Brewster DJ. The aerosol box for intubation in coronavirus disease 2019 patients: an in $\square$ situ simulation crossover study. Anaesthesia. 2020;75(8):1014-21. 
medRxiv preprint doi: https://doi.org/10.1101/2022.01.24.22269341; this version posted January 25, 2022. The copyright holder for this preprint (which was not certified by peer review) is the author/funder, who has granted medRxiv a license to display the preprint in perpetuity.

All rights reserved. No reuse allowed without permission.

319 18. Fennelly KP. Particle sizes of infectious aerosols: implications for infection control.

The Lancet Respiratory Medicine. 2020; 8(9): 914-924 


\section{Table Legends}

323 Table 1: Aerosol and droplet count in high-fidelity clinical simulations of endotracheal

324 intubation (ETI)

325 Table 2: Overall comparison of aerosol and droplet counts

\section{Figure Legends:}

328 Figure 1A: Components of the Airway Shield ${ }^{\mathrm{TM}}$ barrier mouthpiece device; Front view.

329 Figure 1B: Components of the Airway Shield ${ }^{\mathrm{TM}}$ barrier mouthpiece device; Rear view.

330 Figure 1C: Components of the Airway Shield ${ }^{\mathrm{TM}}$ barrier mouthpiece device; Right side 331 view.

332 Figure 2: Functional position of the Airway Shield ${ }^{\mathrm{TM}}$ : Working channel allocated 333 between the tongue and the palate; shield covering the patient's mouth

334 Figure 3A: Endotracheal intubation with the aid of the Airway Shield ${ }^{\mathrm{TM}}$ : Insertion.

335 Figure 3B: Endotracheal intubation with the aid of the Airway Shield ${ }^{\mathrm{TM}}$ : Laryngoscopy.

336 Figure 3C: Endotracheal intubation with the aid of the Airway Shield ${ }^{\mathrm{TM}}$ : Intubation.

337 Figure 4: Simulated induction during ETI and CPR in aerosol manikin model.

338 Figure 5: Simulated induction during ETI with HFNC oxygenation in droplet manikin 339 models.

340 Figure 6: Risk of aerosol and droplet spread during different moments of the intubation 341 procedure. Aerosol and droplet counts, in pixels, are depicted in the logarithmic scale. 
medRxiv preprint doi: https://doi.org/10.1101/2022.01.24.22269341; this version posted January 25, 2022. The copyright holder for this preprint (which was not certified by peer review) is the author/funder, who has granted medRxiv a license to display the preprint in perpetuity.

All rights reserved. No reuse allowed without permission.

\section{Additional Files}

344 Additional File 1: Manikin Preparation

345 Additional File 2: Multimedia Content

346 Additional File 3: Dataset with all 24 shots from the 8 simulated scenarios during CPR

347 and HFNC in droplet and aerosol manikin models performed for the study. Figures with

348 original color photos, black and white photos, and digital pixel counts. 
Table 1

Aerosol and droplet count in high-fidelity clinical simulations of endotracheal intubation $(\mathrm{ETI})$

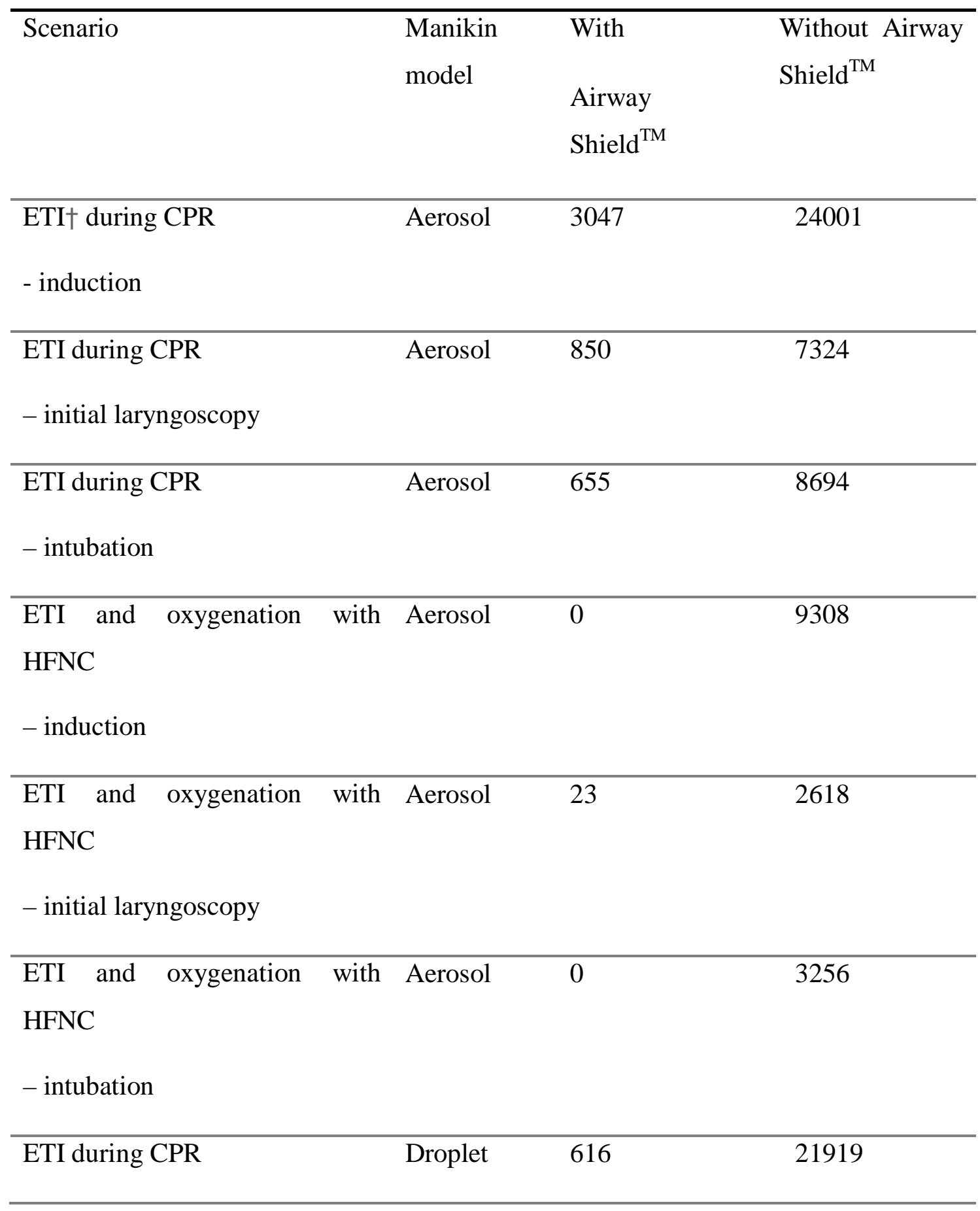


medRxiv preprint doi: https://doi.org/10.1101/2022.01.24.22269341; this version posted January 25, 2022. The copyright holder for this preprint

(which was not certified by peer review) is the author/funder, who has granted medRxiv a license to display the preprint in perpetuity.

All rights reserved. No reuse allowed without permission.

\begin{tabular}{|c|c|c|c|}
\hline - induction & & & \\
\hline ETI during CPR & Droplet & 616 & 7178 \\
\hline - initial laryngoscopy & & & \\
\hline ETI during CPR & Droplet & 206 & 583 \\
\hline - intubation & & & \\
\hline ETI and oxygenation with & Droplet & 78 & 37142 \\
\hline $\mathrm{HFNC}$ & & & \\
\hline - induction & & & \\
\hline
\end{tabular}

ETI and oxygenation with Droplet 1
HFNC

- initial laryngoscopy

\begin{tabular}{llll}
\hline ETI and oxygenation with Droplet & 16 & 2 \\
HFNC & & \\
- intubation & & & \\
\hline Mean $( \pm$ SD) & 509 & 10168.91 \\
& & $(859.96) *$ & $(11600.63) *$
\end{tabular}

Results are measured in pixels. ${ }^{*} \mathrm{P}=0.015$. $† \mathrm{ETI}$, endotracheal intubation; $\mathrm{CPR}$, cardiopulmonary resuscitation; HFNC, high-flow nasal prongs; SD, standard deviation. 
medRxiv preprint doi: https://doi.org/10.1101/2022.01.24.22269341; this version posted January 25, 2022. The copyright holder for this preprint (which was not certified by peer review) is the author/funder, who has granted medRxiv a license to display the preprint in perpetuity.

All rights reserved. No reuse allowed without permission.

Table 2

Overall comparison of aerosol and droplet counts

\begin{tabular}{lcc}
\hline Manikin model & With Airway Shield $^{\mathrm{TM}}$ & Without Airway Shield $^{\mathrm{TM}}$ \\
\hline Aerosol & $762.5(1178.79) *$ & $9200.16(7765.44) *$ \\
\hline Droplet & $255.5(288.45)$ & $11137.67(15281.02)$ \\
\hline Total & $509(859.96) *$ & $10168.91(11600.63) *$ \\
\hline
\end{tabular}

Results are measured in pixels. ${ }^{*} \mathrm{P}<0.05$. 
Figure $1 \mathrm{~A}$

(1)

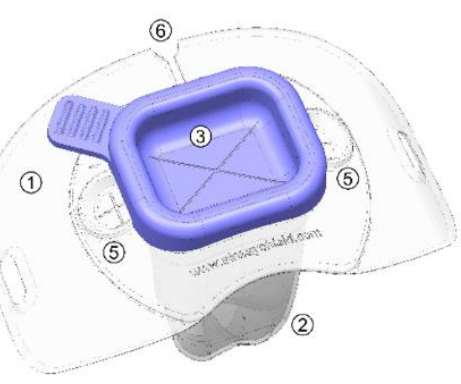

Figure 1B

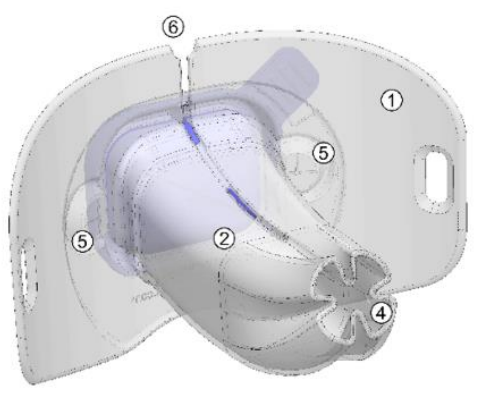

Figure 1C

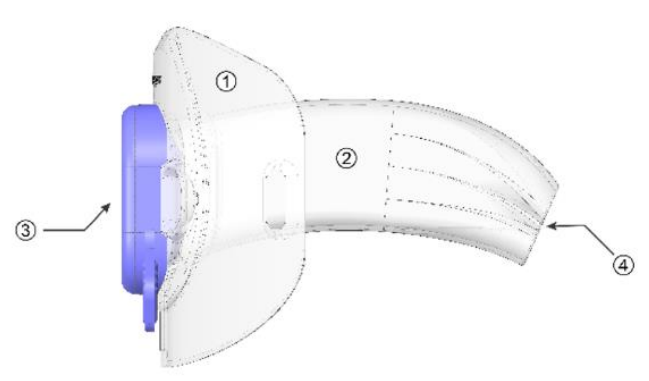

1. Shield

2. Working channel

3. Seal of the proximal opening of the working channel

4. Distal opening of the working channel

5. Suction ports

6. Line for peel-off removal 
Figure 2

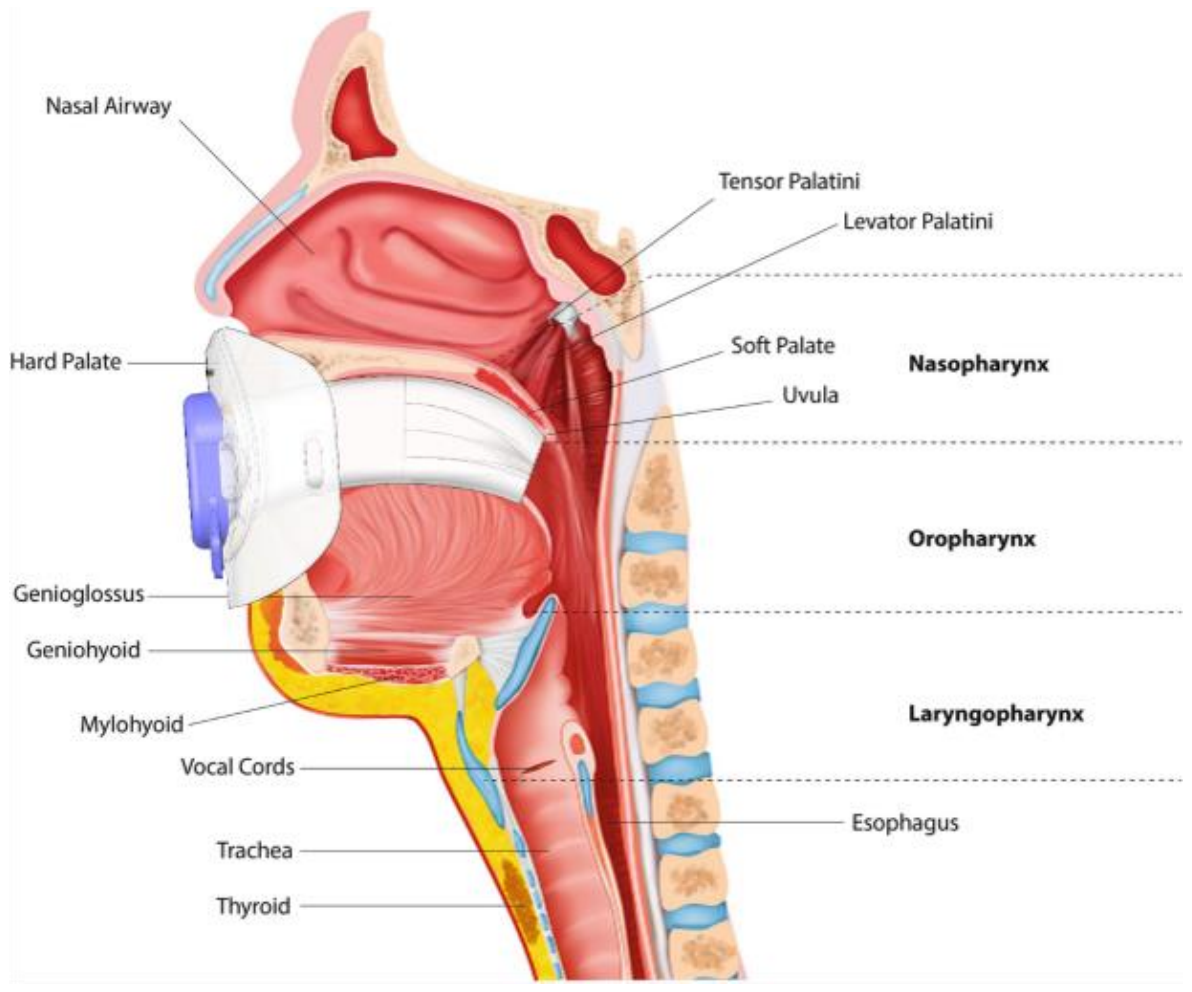


medRxiv preprint doi: https://doi.org/10.1101/2022.01.24.22269341; this version posted January 25, 2022. The copyright holder for this preprint (which was not certified by peer review) is the author/funder, who has granted medRxiv a license to display the preprint in perpetuity.

All rights reserved. No reuse allowed without permission.

Figure 3A
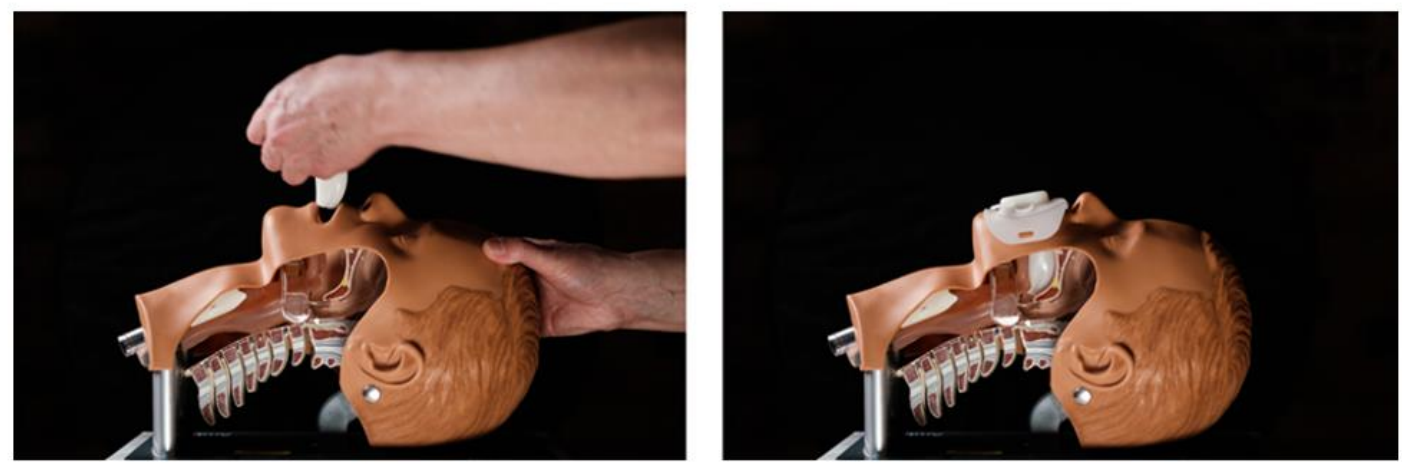

Figure 3B
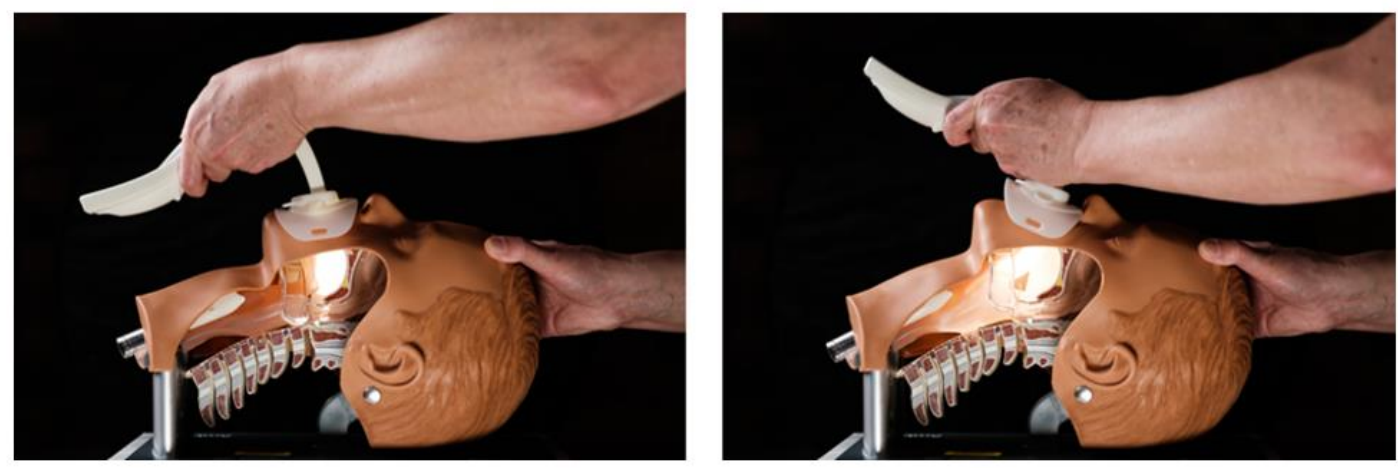

Figure 3C
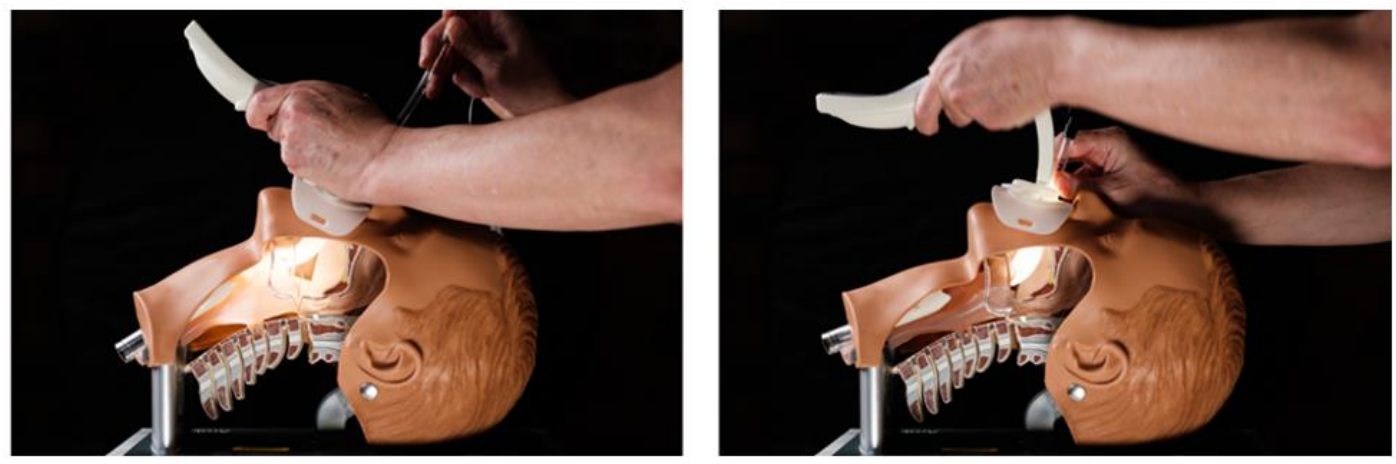
Figure 4
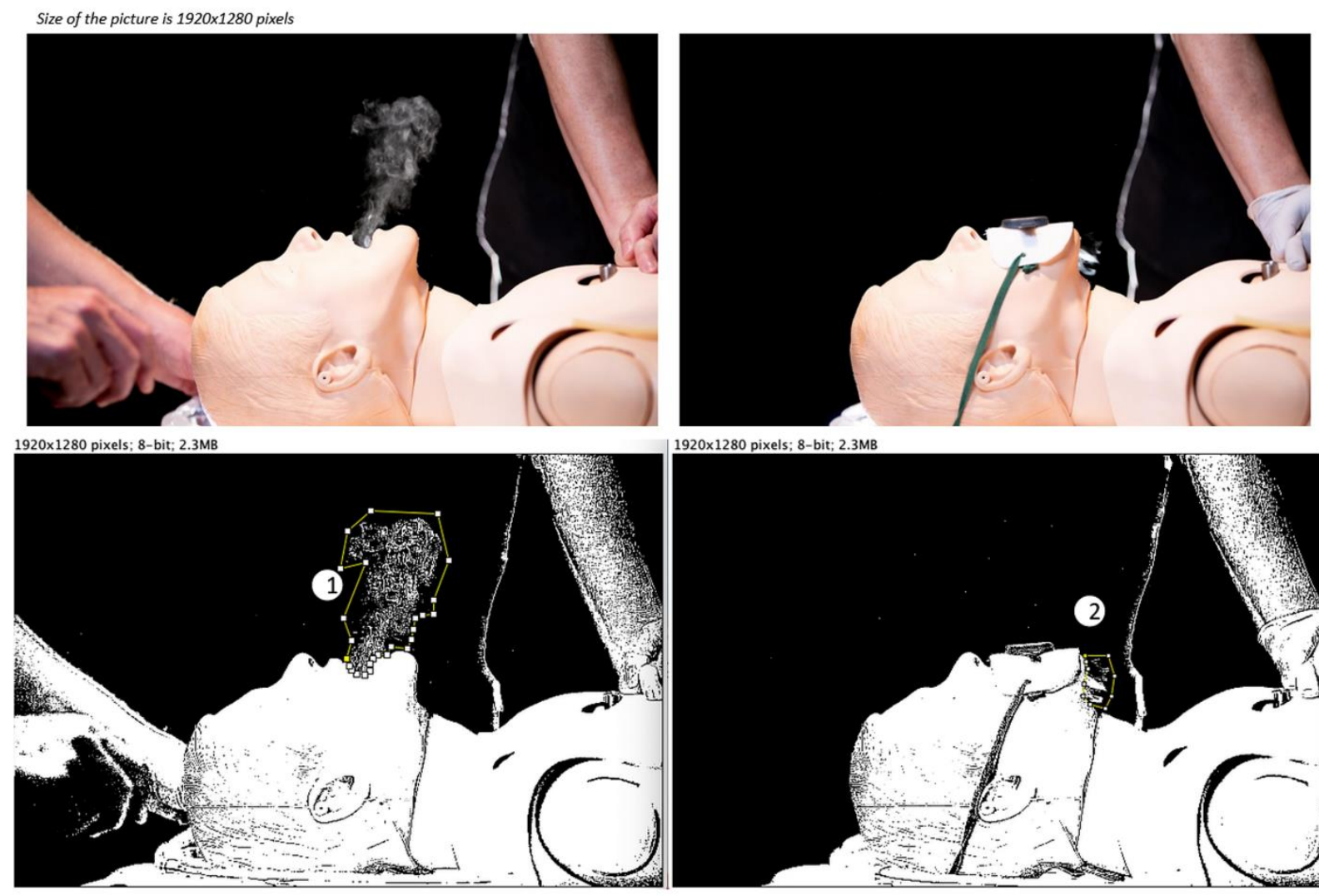

$1920 \times 1280$ pixels: 8 -bit: $23 \mathrm{MB}$
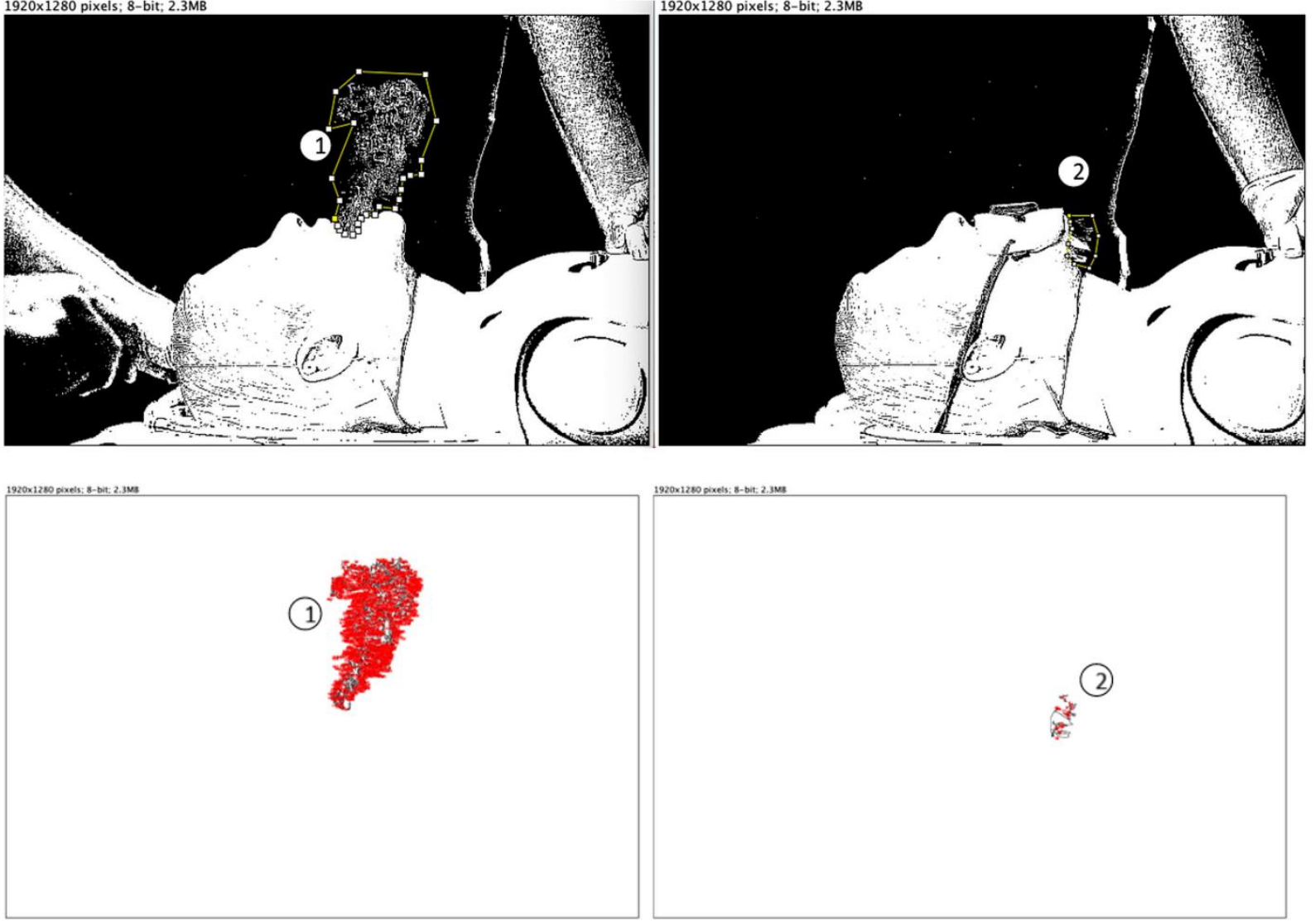

Result:

\begin{tabular}{l|l|l|l|}
\hline Slice & Count & Total Area & Average Size \\
(3) Scenario 1.1.jpg & 1104 & 24001 & 21.740 \\
(3) Scenario 2.1.jpg & 28 & 3047 & 108.821
\end{tabular}


medRxiv preprint doi: https://doi.org/10.1101/2022.01.24.22269341; this version posted January 25, 2022. The copyright holder for this preprint (which was not certified by peer review) is the author/funder, who has granted medRxiv a license to display the preprint in perpetuity.

All rights reserved. No reuse allowed without permission.

Figure 5

Size of the picture is $1920 \times 1280$ pixels
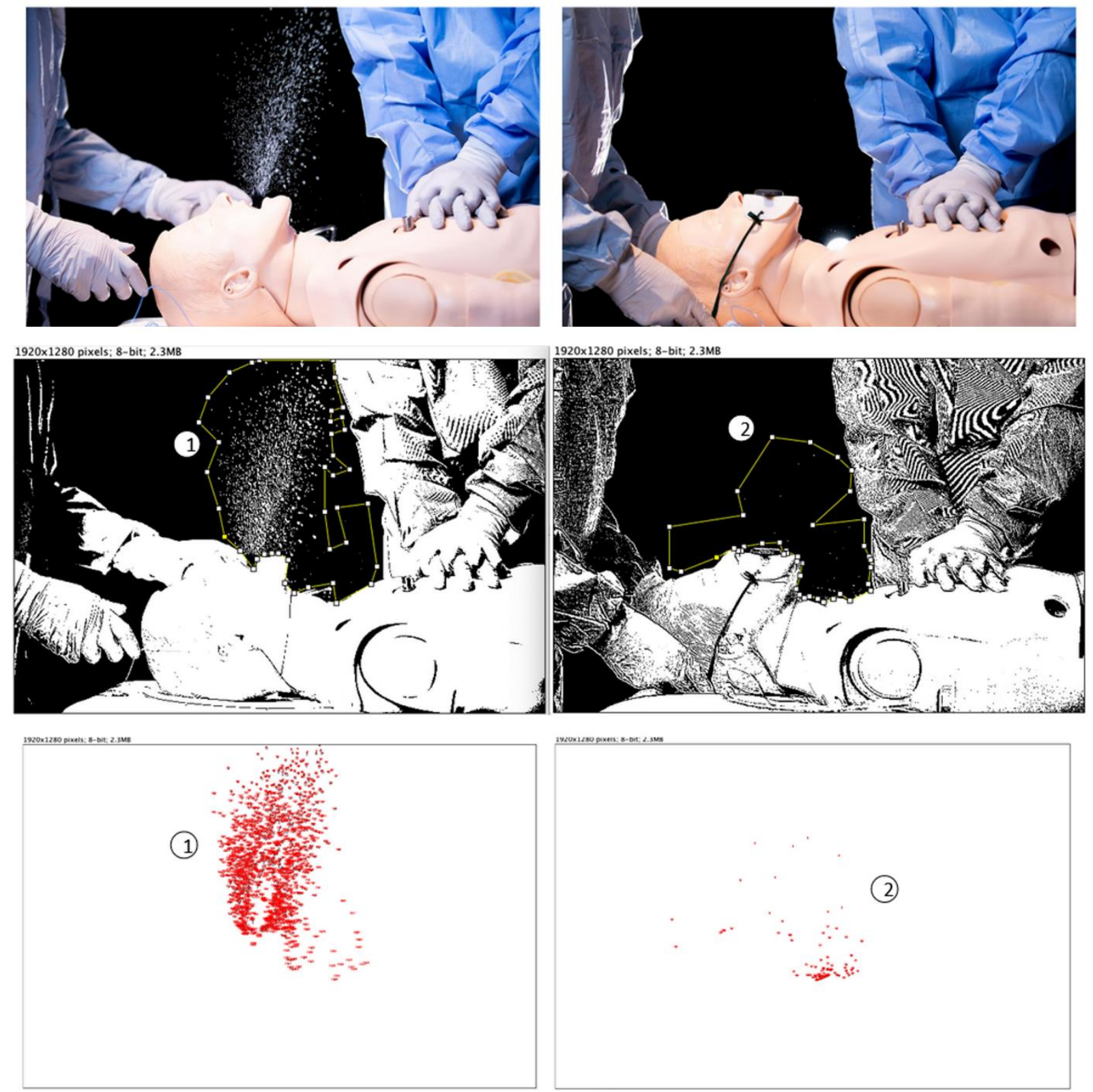

Result:

\begin{tabular}{ll|l|l|}
\hline Slice & Count & Total Area & Average Size \\
\hline Scenario 5.1.jpg & 1126 & 21919 & 19.466 \\
O) Scenario 6.1.JPG & 87 & 616 & 7.080 \\
\cline { 2 - 3 } & \multicolumn{3}{|c|}{ (Unit of area: PIXEL) }
\end{tabular}


medRxiv preprint doi: https://doi.org/10.1101/2022.01.24.22269341; this version posted January 25, 2022. The copyright holder for this preprint (which was not certified by peer review) is the author/funder, who has granted medRxiv a license to display the preprint in perpetuity.

All rights reserved. No reuse allowed without permission.

Figure 6
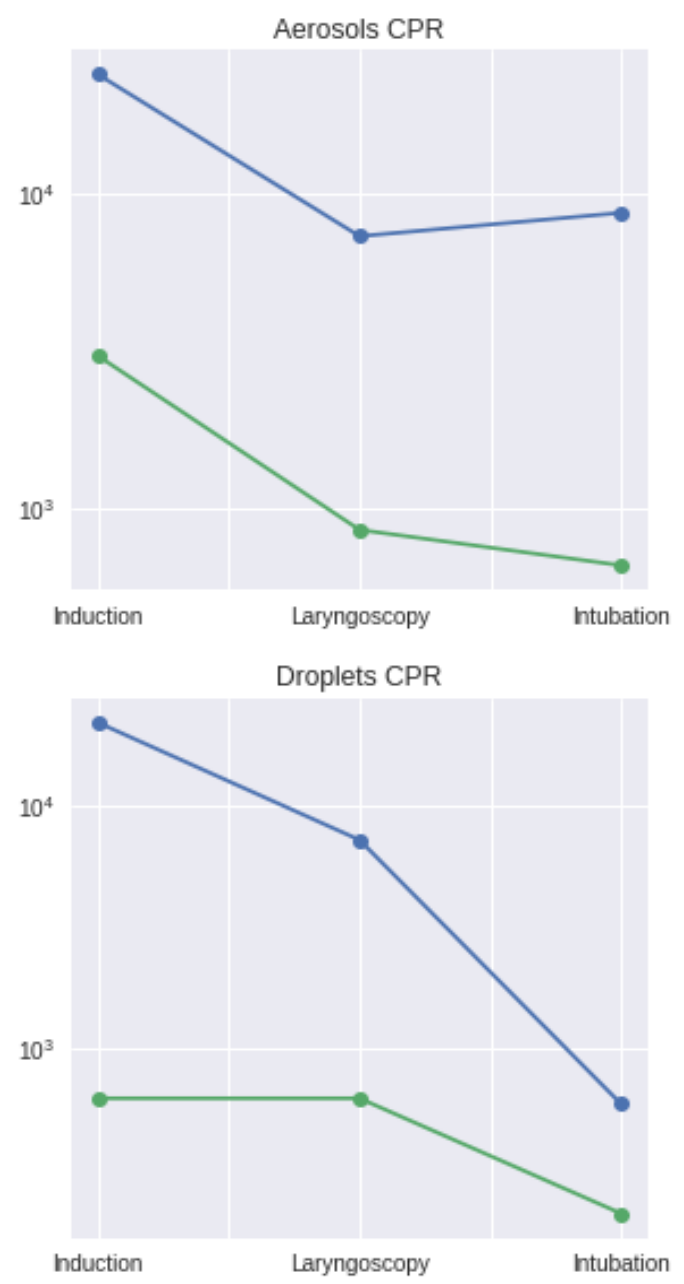

WITH AIRWAY SHIELD

WITHOUT AIRWAY SHIELD
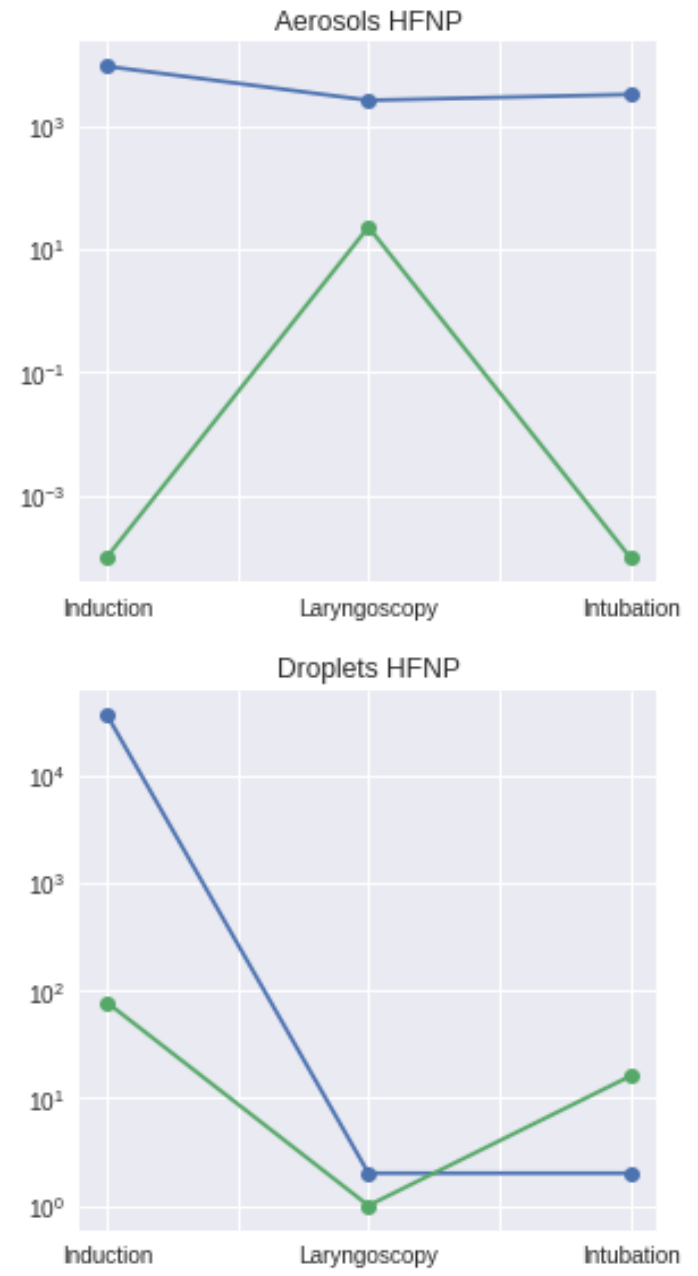